\title{
10. Has the European Social Fund been effective in supporting young people?
}

\author{
Margherita Bussi, Bjørn Hvinden and \\ Mi Ah Schoyen ${ }^{1}$
}

\section{INTRODUCTION}

The European Social Fund (ESF) constitutes a somewhat exceptional and paradoxical part of European Union policy. The division of decisionmaking powers or jurisdiction between EU-level bodies and the member states has meant that national governments have been reluctant to let the EU increase its powers in the wide area of employment and social policies (Ashiagbor, 2005). For many observers, the EU's primary contribution in the realm of social protection and employment has been one of 'social regulation' rather than 'social redistribution'. Briefly, social regulation is public action to promote social goals by influencing the functioning of markets and the behaviour of non-public actors (Majone, 1993). However, under the headings of EU regional ('cohesion') policy, there were always elements of social redistribution at the European level (Allen, 2005). Nonetheless, policymakers perceived such redistribution of resources not as a goal in itself but mainly as an instrument for achieving macro-level objectives: economic growth, modernization, restructuring, and enhancing the four EU freedoms (free movement of goods, capital, services and labour). Currently, the ESF contributes to the achievement of 'a smart, sustainable and inclusive growth in the EU', as defined in the Europe 2020 strategy (Regulation [EU] 1304/2013). Furthermore, the widely spread 'social investment' rationale makes economic redistribution through the ESF a means to achieve societal objectives that go beyond ensuring or improving the current well-being of citizens. Still, high unemployment

1 The authors would like to thank Marianna Georgallis, Elodie Fazi, Vincent Lebrou, Josua Gräbener for useful comments on previous versions of the chapter. The usual disclaimer applies. 
and increasing poverty risks put the individual social welfare of vulnerable sub-groups in the population under pressure. In particular, young people have been hit hard by the economic crisis, and the ghost of a 'lost generation' is threatening their future employment trajectories (see Karamessini et al., Chapter 2 this volume).

To account for the challenging economic context, the ESF has refocused its priorities in recent years (Regulation [EU] 1304/2013). Young people represented 30.5 per cent or just over 30 million of total participations in ESF-funded programmes in the period 2007-13 (European Commission, 2016h). It should be noted that in the below text we refer either to number of 'participants' or number of 'participations'. Participants are single individuals who enter ESF programmes in a given year, whereas participations are the total number of individuals who took part in ESF programmes, whereby the same person can take part in more than one measure. The number of participations is thus equal to or higher than the number of participants.

The ESF either funded or co-funded a large share of the training or employment-related measures available for supporting young people at risk of exclusion in several member states, though to different degrees. The aim of this chapter is to retrace the relevance of youth as a target population of the ESF over time and to show how ESF support for young people has evolved in the EU-28, with a particular focus on Bulgaria, the Czech Republic, Germany, Greece, Poland, Spain and the United Kingdom - the seven member states covered in the NEGOTIATE project. We compare across these countries how ESF support for young people has been designed and distributed.

The chapter first looks at what existing research says about the role of the ESF in dealing with labour market and social integration issues. Our literature review suggests that there is a lack of research examining the targeting of ESF resources towards specific objectives and particular population groups. Motivated by the lack of systematic research on the representation of young people in ESF-funded activities, we offer a brief historical review of the ESF's priorities and focus on young people. In the second part of the chapter we examine available EU documents, existing comparative and time-series data about the role of ESF measures in the past, and ongoing efforts to strengthen the position and employability of young people in the seven EU countries covered by the NEGOTIATE project. We summarize what these data say about the efforts deployed in the 2007-13 and the 2014-20 funding periods. As far as possible, we discuss the relevance of the ESF in the seven NEGOTIATE countries - how strongly young people have been involved in ESF measures, and how this involvement has varied across countries. We also investigate 
whether the involvement of young people has been proportional to the share of NEETs in the country. Finally, we try to: (1) draw lessons based on available cross-national data from the previous (2007-13) and the current (2014-20) ESF funding periods at the national level; and (2) identify lessons for further policy developments to improve the impact of ESF measures on the employment situation of young people in Europe.

\section{THE ESF AND ITS LABOUR MARKET POLICIES AND TARGETS: A MISSING PIECE IN EU POLICY RESEARCH}

Even though the impact of EU policies is a much-researched topic, few labour market or social policy researchers have shown an interest in the ESF and how it affects employment and social welfare (but for a brief discussion, see De la Porte, 2017). Given the noted redistributive character of the ESF, the present chapter is founded on the view that the ESF warrants more attention from a welfare policy perspective. The relatively few existing studies mainly focus on the implementation and impact of ESF funds in a single country or in a small number of countries (e.g., Bonnet, 2015; Dănescu and Dogar, 2012; Sanchez Salgado, 2013; Tomé, 2012; Van Gerven et al., 2014; Verschraegen et al., 2011; Zimmermann, 2016).

Amongst these studies, the article by Verschraegen et al. (2011) offers the best-developed analytical framework, focusing on how the ESF may influence member states' policies through domestic actors' strategic 'usage' of funds, for example by transforming ESF resources into tools for pursuing domestic goals, influencing specific policy decisions, increasing actors' own capacity or accessing political processes. Similarly, the analysis by Ashiagbor (2005: 195-8) of the increasingly important role of the ESF in the emerging common EU employment policy highlights how the European-level use of the ESF has altered the balance between intergovernmentalism and supranationalism in the EU.

Comparative evaluations of the ESF have been mostly commissioned by the European Commission and have encountered a series of challenges. The final synthesis report from the 2007-13 funding period stresses the lack of high-quality comparative data on policy outcomes - such as job entry or qualifications obtained - across member states (ESF Expert Evaluation Network, 2014).

To our knowledge, only few evaluations or studies have focused on a single thematic issue and investigated how its relevance has changed over time at the European level (for a gender perspective, see Brine, 1992, 1995). Moreover, little attention has been given to the distribution of funding 
towards vulnerable sub-groups of the population across ESF-funded actions (European Commission, 2016i: 40). There seems to be potential for more research, and this chapter represents a first step in this regard. Next, we offer a brief historical review of the extent to which young people have been a target group in the objectives and allocation of ESF resources.

A recent exception to this overall picture is the study by Tosun et al. (2017). They examine what impact member states' absorption of Structural and Investment Funds (including ESF) has on changes in the levels of youth unemployment. They conclude that exhausting funds has a significant effect on youth unemployment.

Data from Eurostat and the World Bank (not shown) illustrate cyclically high levels of youth unemployment in Europe since the late 1980s, ranging - for the different configurations of the European Community - from 15 per cent to 25 per cent. The following historical overview suggests that volatile and high levels of youth unemployment are not the only explanation for the relevance of young people as a policy target. The overall European economic strategy of the moment and changes in the management of the ESF also help explain why young people have been amongst the participants in ESF measures for a long time, without always being a specific priority.

The ESF was established under the Treaty of Rome in 1957. Since then, it has redistributed huge financial resources for the realization of goals that - directly or indirectly - have had a substantial impact on many EU citizens' employment, living conditions and social welfare. It is the oldest of the EU's policy instruments to address labour market challenges and to promote labour market integration (Lindley, 1996: 843). The Treaty of Rome set up the ESF as a tool for implementing social and labour market policy within the newly created European Community. The aim was to improve the geographical and professional mobility of European workers by providing vocational training and financial support for resettlement. Young people were not mentioned as a target group by the recently born Community, which mostly considered supporting the workforce as an instrument towards developing the economy rather than a social objective per se.

With the enlargement in 1973, European regional policy was better defined. A new reform in 1983 (under Council Decision 83/516/EEC) led to a greater concentration of the ESF's targets. In the early 1980s efforts were mainly directed at the fight against rising unemployment amongst youth and other disadvantaged workers. The policies targeted young people struggling in the labour market by providing vocational training or support to complete compulsory education.

The entry of Ireland, Greece, Spain and Portugal played in favour 
of increased spending towards poor regions and less towards agriculture. In 1986 the Single European Act streamlined the existing funds (ESF, European Regional Development Fund and European Agricultural Guidance and Guarantee Fund) under the label 'Structural Funds' and defined objectives and geographical areas in which money should be concentrated to support cohesion policies.

An important budgetary reform implemented in 1988, known as the Delors I Package, introduced general regulatory guidelines, strategic decisions and a major cash injection for the upcoming five-year funding period (1989-93; for details, see Lindley, 1996). Several new governance principles were approved to increase the efficacy of the funds: concentration on a series of five objectives; programming over five years drawn up by member states but in line with the priorities of the Community; a partnership approach favouring the development of horizontal and vertical coordination; and adherence to the 'additionality' principle stipulating that EU funding comes in addition to rather than replaces national public expenditure.

Table 10.1 summarizes the changing focus on young people in the objectives of the Structural Funds over the past 30 years. In the period 1989-93 young people were still a priority target for European funds. Objective 4 of the Structural Funds defined the target group of ESF funding as unemployed young people under 25 who have finished compulsory education (Council Regulation [EEC] 2052/88). While this objective clearly focuses specifically on projects targeting young unemployed in transition from compulsory school to work, additional support for young people could be funded under different objectives via apprenticeships and vocational education and training (VET). Support for vocational training is central to the ESF because, ever since the early days of European regional policy, it is considered a premium tool for overcoming skills obsolescence, promoting mobility of workers and combatting unemployment (Council Regulation [EEC] 2052/88). A second ESF regulation approved in December 1988 defined the measures that were eligible for ESF funding under Objective 4. Interestingly, the regulation specifies that measures are meant to support young people under 25 who have completed compulsory education and are looking for employment, irrespective of the length of their job-search period. In times of high unemployment (almost 19 per cent in the EU-12 in 1988, according to World Bank data ${ }^{2}$ ) the ESF fund was used to broadly target young people and provide early intervention to ease young people's transitions. To some extent, the objective of that time seems to anticipate

2 See http://databank.worldbank.org/data/reports.aspx?source=2\&series=SL.UEM.TO TL.ZS\&country= (accessed: 20 April 2018). 


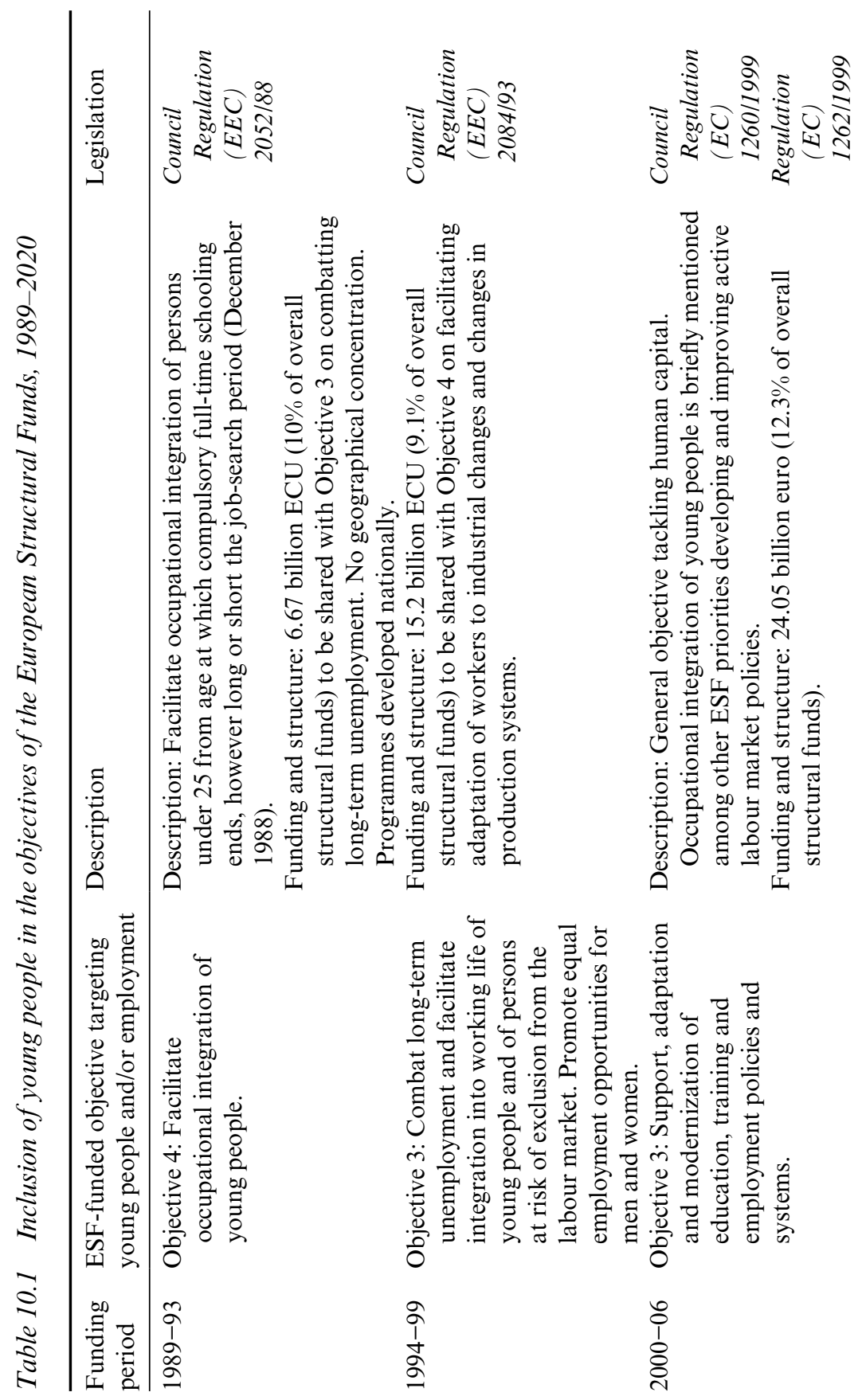




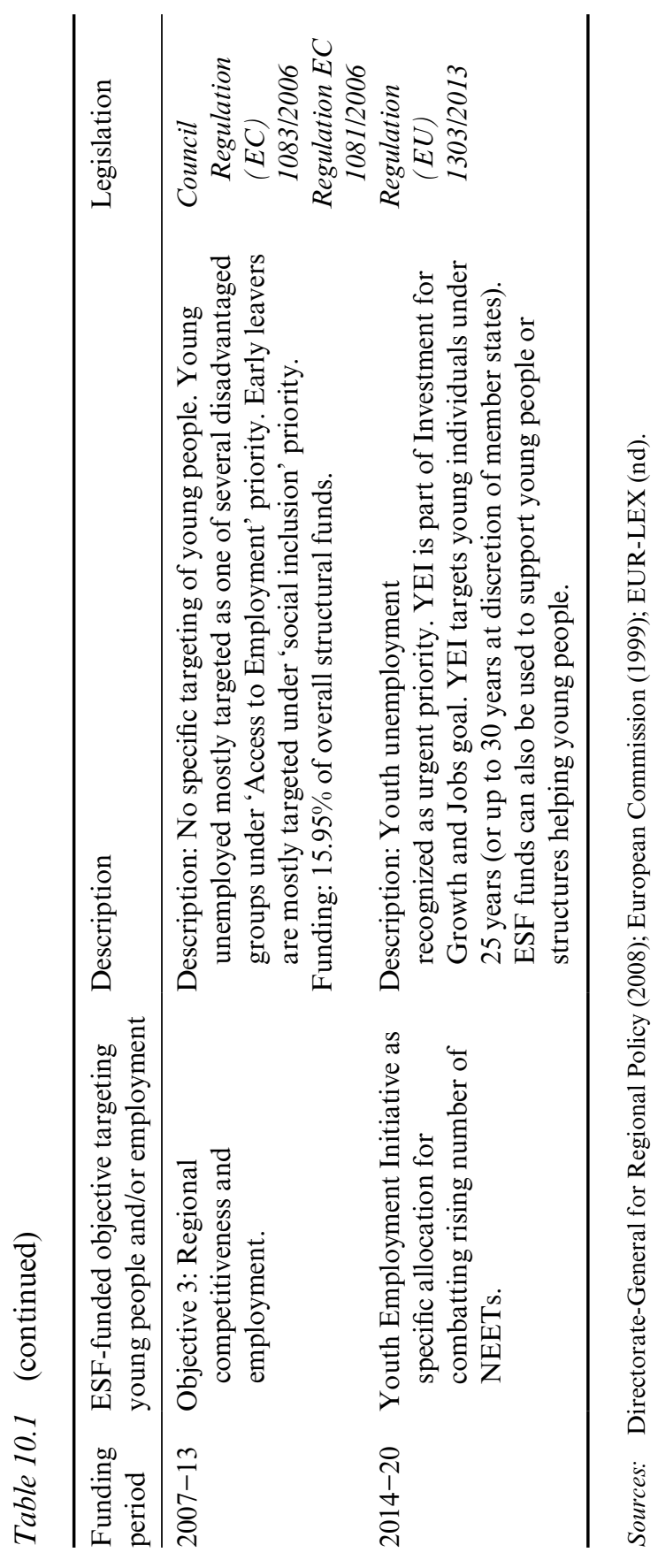


the current Youth Guarantee scheme (see Dingeldey et al., Chapter 9 this volume).

Economic and social cohesion became a formal objective in 1992 under the Treaty of Maastricht. In 1993 the regulations and objectives for the Structural Funds were revised. In the early 1990s youth unemployment was again on the rise, reaching as much as 20 per cent in the EU-12 in 1993 and peaking at 21.7 per cent in 1996 in the enlarged EU-15. Combatting unemployment remained a priority for the ESF. However, Objective 4 was merged into Objective 3, which also included long-term unemployed, persons at risk of exclusion from the labour market and gender equality in employment opportunities. Consequently, although they remained one of several prioritized groups considered vulnerable in the labour market, there was no longer a specific objective devoted to the labour market challenges of young people.

An example of the kind of measures that received support from the ESF in the funding period 1994-99 were the Community Initiatives for Innovative Actions. These initiatives enabled the pilot programme YouthStart, which specifically targeted young people under 20 with no basic qualification or training who were finding it difficult to enter the labour market (European Commission, 1999). Overall during this funding period, most attention was given to industrial decline and the ensuing production and workforce changes. The lion's share of the available Structural Funds always went to Objective 1 regions, targeting their economic structure.

In 1999, with the entry into force of the Treaty of Amsterdam and the introduction of the new and longer funding period (seven instead of six years, from 2000-06), the objectives of the ESF were revised. While Objectives 1 and 2 remained almost unchanged, Objective 3 (vulnerable groups) and Objective 4 (adaptation to industrial changes) were merged into one more general Objective 3 with no specific targeting and referring broadly to education and employment (see Table 10.1). This referred back to the new chapter on employment introduced in the Amsterdam Treaty and the pillars of the new European Employment Strategy (i.e., employability, adaptability, entrepreneurship and equal opportunities; Goetschy, 1999), to which the ESF was expected to contribute. In contrast with the previous funding period, none of the revised objectives now focused explicitly on young people. Initiatives were streamlined, and objectives were more general in terms of the targeted groups. The broader scope of objectives and Community Initiatives were coupled with new funding and governance rules; in addition, closer monitoring and financial management of these funds was implemented (European Commission, 1999; Manzella and Mendez, 2009).

The following funding period (2007-13) was particularly significant. 
The 2004 enlargement and the entry of Romania and Bulgaria in 2007 changed the composition of the European workforce, and in 2008 the financial crisis spread to the real economy. In 2006, based on the Lisbon Strategy, its mid-term review in 2005 and the underlying Kok report, the Structural and Cohesion funds underwent a major reform. Objectives 1, 2 and 3 of the previous funding period were redefined into three broader objectives: convergence, regional competitiveness and employment, and territorial cooperation (Manzella and Mendez, 2009). The ESF-specific provisions very briefly referred to young unemployed and early schoolleavers as disadvantaged groups.

Throughout the first part of the 2007-13 funding period the main priority in most member states was to keep the prime-age workforce in work or some form of activity. Employer subsidies and training or mobility investments sought to prevent the depreciation of their human capital and enhance their long-term employability. Some way into the 2007-13 programme, leaders both at national and European levels realized that young people were amongst those hardest hit by the Great Recession (in 2008 there had been a stark increase in youth unemployment). Based on a mid-term review of the 2007-13 programme, the EU decided to shift its priorities towards preventing long-term exclusion of young people in the last part of the programme period. A subsequent evaluation indicated that the member states followed up this shift in operational goals to a variable extent (European Commission, 2016i: 40).

With a dedicated budget line - the Youth Employment Initiative (YEI) EU Regulation 1304/2013 for the 2014-20 ESF period gives much stronger and consistent priority to combatting youth unemployment and exclusion than the regulations for earlier periods. Hence, under the current funding period, young unemployed and inactives can benefit from 'traditional' ESF support as well as the YEI (also see Dingeldey et al., Chapter 9 this volume). The latter involves substantial financial resources of 3.2 billion euros from the EU channelled through the ESF. Recipient countries are to match ESF funding with an equivalent amount of national co-funding.

\section{OVERALL SCALE OF ESF FUNDING AND PARTICIPATION}

In the period 2007-14, the ESF had almost 100 million participations (European Commission, 2016h). Since one and the same person may have participated in more than one measure, it is not possible to establish the total number of young individuals who took part in ESF-funded activities during the years 2007-14. 


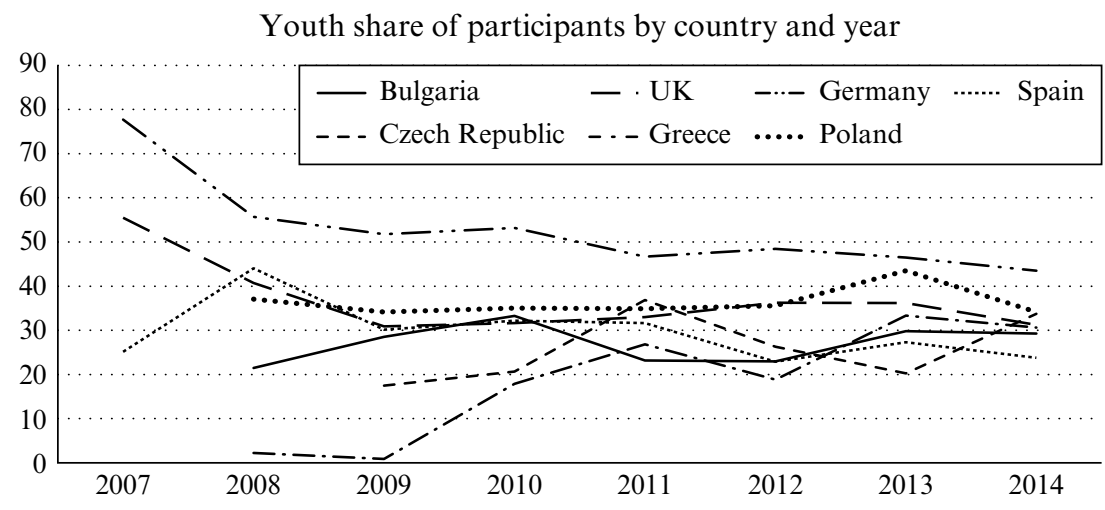

Source: ESF Internet database and Eurostat database.

Figure 10.1 Percentage of young people (aged 15-24) as a share of total ESF participations per year, by country

Figure 10.1 shows the share of young people among participations in ESF measures between 2007 and 2014. During the whole period, the share of young people in ESF measures in Germany was higher than in any other country. At all times during the funding period, young people accounted for more than 42 per cent of ESF participants. The other countries showed lower percentages, although the shares of young people converged towards the end of the funding period, probably because of the timing of implementation. In each year young people made up between 30 per cent and 40 per cent of participants in both Poland and the United Kingdom. For Greece and the Czech Republic, no participations in the first two or three years might have been caused by a delay in implementation. Although shares varied across countries, it seems that (considering their proportion of the population) young people were a net beneficiary of ESF support compared to other age groups.

The ESF had a rather complex structure of priorities or operational goals in the period we are observing (2007-13). Arguably, its goals were not mutually exclusive, rather partially overlapping. Moreover, member states seem to have had great discretion regarding which of these goals they prioritized. The ESF supported actions in relation to six goals, four of which are relevant in this context (ESF Expert Evaluation Network, 2014: 10-11):

1. Increasing adaptability of workers, enterprises and entrepreneurs to improve the anticipation and positive management of economic change ('Adaptability'). 
2. Enhancing access to employment and the sustainable labour market inclusion of jobseekers and inactive people; preventing unemployment, especially long-term and youth unemployment; encouraging active ageing and longer working lives; and increasing labour market participation ('Access to Employment').

3. Reinforcing the social inclusion of disadvantaged people with a view to their sustainable integration in employment, and combatting all forms of labour market discrimination ('Social Inclusion').

4. Enhancing human capital/expanding and improving investment in human capital ('Human Capital').

Table 10.2 provides a brief overview of the distribution of young people across these four intervention priorities. Figure 10.1 showed that young people were heavily involved in ESF measures in Germany; here we see that they represented 56 per cent of participations in the Human Capital priority and 34 per cent of Access to Employment. Young people were less involved in Greece in that they accounted for less than a third of the Human Capital priority as well as less than 10 per cent of Access to Employment and Social Inclusion. Similar percentages are found in the Czech Republic. Young people participated massively in Human Capital measures in Spain (73 per cent) and they represented more than half of Human Capital participations in Poland.

Data for 2012 presented in Caliendo and Schmidl (2016) showed that young people represent around 10 per cent of ALMP participants in Germany, around 17 per cent in Spain and less than 5 per cent in Poland. If we compare the share of young people taking part in ALMPs at the national level with the figures from the ESF, it appears that ESF measures

Table 10.2 Percentages of young people's participations by different ESF priorities, 2007-13

\begin{tabular}{lccccccc}
\hline & Bulgaria & $\begin{array}{c}\text { Czech } \\
\text { Republic }\end{array}$ & UK & Greece & Germany & Poland & Spain \\
\hline Adaptability & missing & 3.9 & n.a. & 4.7 & n.a. & 11.5 & 15.7 \\
$\begin{array}{l}\text { Human } \\
\quad \text { missing }\end{array}$ & 32.6 & 24.0 & 28.1 & 56.0 & 53.9 & 73.2 \\
$\begin{array}{l}\text { Access to } \\
\quad \text { Employment }\end{array}$ & & & & & & & \\
$\quad \begin{array}{l}\text { Emissing } \\
\text { Social }\end{array}$ & 3.9 & 37.0 & 9.9 & 34.0 & 40.7 & 23.7 \\
$\quad$ Inclusion & missing & 4.0 & - & 8.9 & - & 25.3 & 14.1 \\
\hline
\end{tabular}

Source: European Commission (2016a to 2016g). 
Table 10.3 Amount of total ESF, amount of ESF for Access to Employment priority and relative size of ESF expenditure as compared to total national expenditure on ALMPS (Categories 2-7); period 2007-13

\begin{tabular}{lcccc}
\hline & $\begin{array}{c}\text { ESF total } \\
\text { (million) }\end{array}$ & $\begin{array}{c}\text { National } \\
\text { expenditure on } \\
\text { ALMPs (Cat. 2-7) } \\
\text { (million) }\end{array}$ & $\begin{array}{c}\text { Amount of ESF } \\
\text { for Access to } \\
\text { Employment (A2E) } \\
\text { priority } \\
\text { (million) }\end{array}$ & $\begin{array}{c}\text { Ratio of A2E } \\
\text { expenditure to } \\
\text { national ALMP } \\
\text { expenditure } \\
\text { (million) }\end{array}$ \\
\hline CZ & 4316 & 1691 & 820.04 & 0.48 \\
BG & 1387 & 557 & 485 & 0.87 \\
DE & 15895 & 85812 & 4132 & 0.05 \\
EL & 5133 & missing & 2123 & missing \\
PL & 1173 & 12593 & 3109 & 0.25 \\
ES & 11202 & 45321 & 7729 & 0.17 \\
UK & 8655 & missing & 5300 & missing \\
\hline
\end{tabular}

Sources: European Commission (2016a to 2016g) for amount of ESF funding and A2E share; Eurostat database.

were more successful at targeting young people and concentrating efforts on the least advantaged groups of the population.

The relative weight of the ESF compared to the national effort is of particular importance for ascertaining the dependence of a country/region on external (EU) support. Table 10.3 reports the relative size of funds spent on the ESF priority Access to Employment in 2007-13 (Regulation [EC] 1081/2006) and the national expenditure on ALMPs (Categories 2 to 7, i.e., costs related to labour market measures). This ESF priority includes measures aiming to help participants reintegrate into the labour market - a similar objective to ALMPs implemented at the national level. The ratio between the two expenditures was much higher in Bulgaria, the Czech Republic and Poland than in the older EU members, Germany and Spain. For Bulgaria, the ESF budget spent on Access to Employment represented 87 per cent of the amount of national funds spent on ALMPs. Similarly, for the Czech Republic and Poland, ESF funds represented an important asset on which fundamental interventions in favour of the unemployed relied. While the ESF funds counted for a very marginal part of the German funds spent on ALMPs, in Spain they represented 17 per cent of the national effort. Unfortunately, complete time series for ALMP spending are missing for Greece and the United Kingdom.

In Table 10.4 we compare the yearly number of young people in 
Table 10.4 Ratio between the number of young people (15-24) in ESF measures and the number of NEETs (15-24), 2007-14

\begin{tabular}{lccccccc}
\hline $\begin{array}{l}\text { Young } \\
\text { participants/ } \\
\text { number of } \\
\text { NEETs }\end{array}$ & BG & CZ & UK & EL & DE & PL & ES \\
\hline 2007 & - & - & - & - & - & - & 0.3 \\
2008 & 0.2 & - & 0.2 & - & 0.4 & 0.2 & 1.2 \\
2009 & 0.4 & 0.3 & 0.4 & - & 0.7 & 0.8 & 0.7 \\
2010 & 0.4 & 1.9 & 0.6 & 0.6 & 0.8 & 1.1 & 0.9 \\
2011 & 0.2 & 5.2 & 0.4 & 0.9 & 0.8 & 0.9 & 0.7 \\
2012 & 0.6 & 6.2 & 0.3 & 0.6 & 1.0 & 0.9 & 0.4 \\
2013 & 1.4 & 5.5 & 0.2 & 1.7 & 0.8 & 1.4 & 0.4 \\
2014 & 1.2 & 7.6 & 0.2 & 1.1 & 0.6 & 1.0 & 0.5 \\
\hline
\end{tabular}

Notes: $\quad-=$ missing or 0 . If the ratio is lower/higher than 1 , this means that the number of young participants in ESF measures is lower/higher than the number of NEETs in the country that year.

Source: European Commission (2016a to 2016g) and Eurostat database; authors' calculations.

ESF measures with the number of young people neither in employment, education or training (NEETs). The ratios do not tell us whether young NEETs in a country were actually involved in ESF measures. Nonetheless, they give us a rough idea of the number of young participants per year compared to the number of needy young people in a given country.

The Czech Republic seems to have been the most successful country in that participations by young people in ESF measures largely outnumbered the number of NEETs. Among the EU-28, the Czech Republic also had the highest shares of ESF participations compared to 1) the total number in education (211 per cent) and 2) the total number aged 15-24 (119 per cent) (European Commission, 2016h: 92). Along with Portugal, the Czech Republic was the only member state in which ESF human capital investments amounted to more than 5 per cent of total investments in human capital (European Commission, 2016h: 118).

The ESF funding for human capital that the Czech Republic received might have meant that a larger share of its young people was in education or vocational training than otherwise would have been the case, thus reducing the number of NEETs as well as the number of young people registered as unemployed. Alternatively, one might ask whether the Czech 
authorities sought to transfer part of the investments in education from the national to the European level.

The ratio of the number of young ESF participants to the number of NEETs in Spain was better at the beginning of the funding period, declining in the second half. This was just the opposite to the trend found in Bulgaria. On the other hand, given its number of NEETs, the United Kingdom seems to have been under-using the ESF in skill-building or employment-promoting measures for young people.

An expert evaluation carried out in 2014 and based on the achievements recorded for ESF measures by the end of 2012 provided the picture summarized in Table 10.5. Achievements are measured as the distribution of young beneficiaries across actions tied to the different goals outlined above. Considering that the member states were still struggling with the consequences of the Great Recession, it is not surprising that enhanced human capital of young participants was the most important achievement for the EU overall. More striking is that improved access to employment was the second-most important achievement. As this overall evaluation did not build on a randomized controlled experiment, we are probably to some extent seeing the result of selection in recruitment to measures, especially in the UK case (which might be consistent with the suggestion

Table 10.5 Distribution of young people's (age 15-24) participations across ESF priorities, end of 2012

\begin{tabular}{lcccc}
\hline & $\begin{array}{c}\text { Enhanced } \\
\text { adaptability } \\
\text { to change }\end{array}$ & $\begin{array}{c}\text { Improved } \\
\text { access to } \\
\text { employment }\end{array}$ & $\begin{array}{c}\text { Improved } \\
\text { social } \\
\text { inclusion }\end{array}$ & $\begin{array}{c}\text { Enhanced } \\
\text { human } \\
\text { capital }\end{array}$ \\
\cline { 2 - 6 } & \multicolumn{2}{c}{ Per cent } & \\
\hline Bulgaria & 10 & 6 & 3 & 77 \\
Czech & 2 & 1 & 1 & 97 \\
$\quad$ Republic & 5 & 21 & - & 74 \\
Germany & 0 & 5 & 0 & 66 \\
Greece & - & - & 8 & 5 \\
Poland & 7 & 37 & - & 0 \\
Spain & 18 & 66 & & 49 \\
United & & & 5 & \\
$\quad$ Kingdom & 10 & 27 & & \\
Total EU & & & &
\end{tabular}

Note: $\quad-=$ data missing.

Source: Authors' calculations. ESF Expert Evaluation Network (2014), Tables 3, 5, 6, 7 and 8 . 
of possibly too limited recruitment, given the number of NEETs in the United Kingdom).

The outcomes in the Czech Republic were almost exclusively enhanced human capital, again indicating that the ESF funding allocated to this country was oriented towards giving upper-secondary and vocational education a boost (or, alternatively, reflecting a shift of funding towards European sources).

Unfortunately, the ex post evaluation of the ESF programmes made clear that few operational plans for the grants had formulated specific result indicators or targets for young people, despite otherwise giving emphasis to young people. The Commission wrote that this made assessment of the results regarding young people impossible (European Commission, 2016i: 21-2). Arguably this points to an important shortcoming of the entire 2007-13 ESF programme and its evaluation that is difficult to understand, especially considering the stronger weight for young people that was agreed for the last part of the programme. The Commission document leaves us with scraps of anecdotal evidence of the following kind:

...the evaluation of some Italian, Spanish and Portuguese support schemes for young unemployed people concluded that training for the young increased their employability and the number of weeks worked per year. (European Commission, 2016i: 34)

According to the same document:

The increased EU-level policy attention to youth unemployment and the introduction of various specific youth employment policies in 2012-2013 did not translate directly into increased participation of young people. . . in the second part of the programming period. (European Commission, 2016i: 40)

The document also points to shortcomings related to different interpretations of common definitions in providing monitoring data, lack of common results indicators, and lack of longitudinal and relevant micro data (European Commission, 2016i: 41) as a basis for a final joint evaluation.

Despite the mentioned deficiencies in the evaluation of the ESF efforts related to young people, the Commission's evaluators felt able to identify the following common success factors amongst a large variety of ESF interventions aimed at young people (European Commission, 2016h: 85):

- The provision of tailored, individualized assistance based on the needs of young people, covering both classroom based learning activities but also out-of-school activities and practical work 
experiences in the real working environment, is a crucial success factor.

- Making use of the experience and knowledge of institutions working closely with young people was successful in reaching out to them.

- Interventions focusing on changing the working relationships between young people, educational institutions and employers contributed to achieving successful results.

- The combination of support provided for the acquisition of both formal qualifications recognized in the education and training system, and the development of general competences and skills (such as how to apply for jobs) added significant value for young people.

To conclude, the data presented above, albeit partial, show that in the countries analysed in this chapter, the share of young people's participations in the ESF converges over the funding period (Figure 10.1), with young people mostly benefitting from funding under the 'human capital' heading. The United Kingdom represents an exception. This might be explained by the traditionally stronger emphasis on ALMPs promoting a return to the labour market. Comparing national statistics on young NEETs and young people's participation in ESF programmes, our calculations show that ESF funds vary greatly in importance across countries.

\section{CURRENT EXPENDITURE AND PARTICIPATION OF YOUNG PEOPLE}

At the time of writing, with regard to the current funding period beginning in 2014, only data for the years 2014 and 2015 were publicly available. Moreover, data are not always available for all the EU member states covered by the NEGOTIATE project. We start by presenting the share of young people taking part in the different ESF priority axes in Table 10.6. Results for the first two years of funding, 2014 and 2015, show that Germany was mostly investing in education and VET. The same was the case for Greece. Spain concentrated its effort - at the regional level - on sustainable and quality employment, as one might expect in a country with dramatically high levels of youth unemployment. The same appeared to be the case in Poland, where young people were mostly taking part in programmes facilitating their entry into the labour market.

For Poland and Spain, the share of young people in sustainable and quality employment measures is much higher than in the previous programming period. Germany and Greece have been investing ESF money 


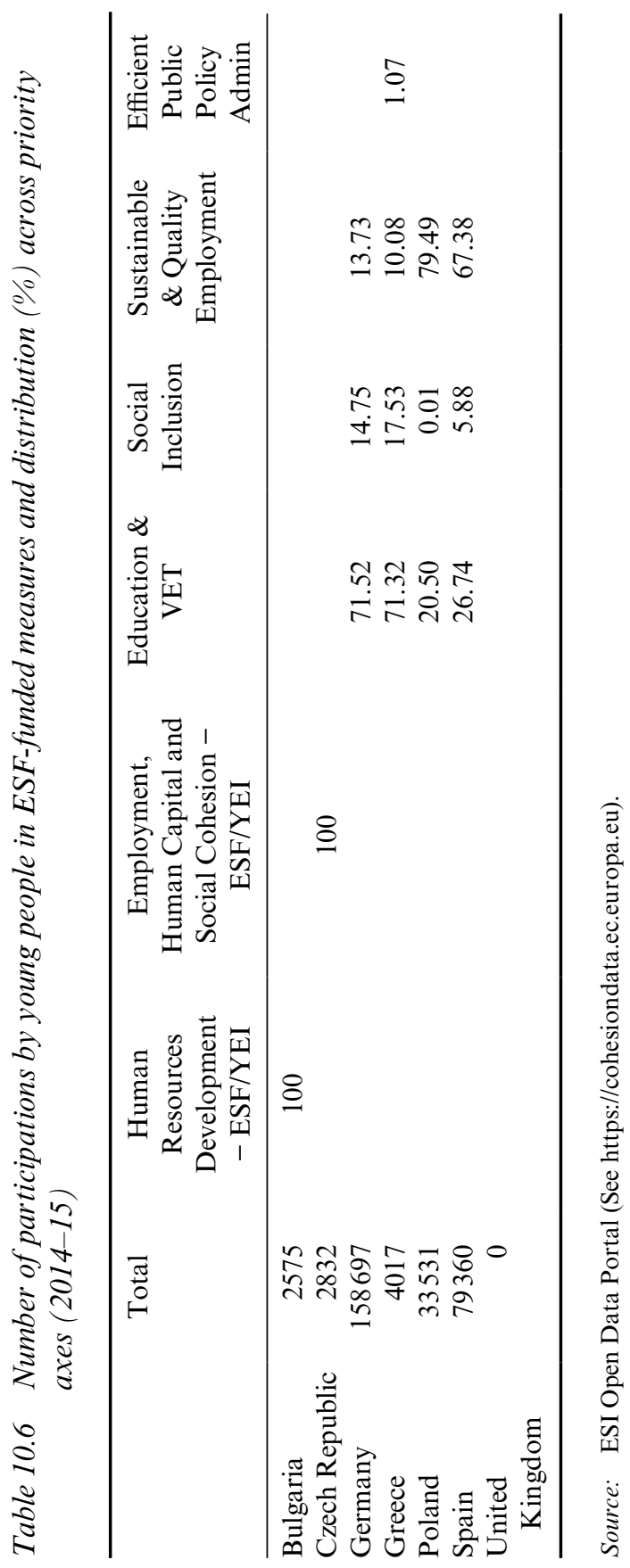


in education and VET, keeping the same investment pattern as in the previous funding period. For Greece, it is important to highlight that the share of young people in ESF-funded measures is higher in the first two years of the current funding period than in the previous funding period.

At the time of writing, detailed YEI data were available only for Greece, Spain and Poland, and for the funding period 2014-15. In the current funding period the YEI has represented an important source of funding for supporting young people and, following a more generous pre-financing system, member states were invited to make use of the YEI as of 2014. Table 10.7 compares the distribution of young people according to their level of education in YEI-funded measures and in the NEET population.

In Spain young people who took part in ESF/YEI-funded measures presented the same educational attainment as the reference population (NEETs), suggesting a good level of targeting. ${ }^{3}$ In Greece low-educated young people were heavily under-represented amongst youth taking part in ESF/YEI measures, accounting only for 3.3 per cent, while they accounted for 23 per cent of the NEET population. In Poland, there seemed to be a better balance than in Greece between the share of YEI participants and the share of NEETs with low education, but a weaker balance than in Spain. In other words, ESF/YEI-funded programmes were more clearly targeted at those with low education in Spain than in Greece or Poland.

Table 10.7 YEI participants and NEETs by educational levels, percentages, 2015

\begin{tabular}{llccc}
\hline & \multicolumn{3}{c}{ Percentage } \\
\cline { 3 - 5 } & & & \\
& & & & \\
\hline \multirow{2}{*}{ Spain low-educated } & of medium-educated & $\begin{array}{c}\text { of highly } \\
\text { educated }\end{array}$ \\
\cline { 3 - 5 } Greece & In YEI & 64.0 & 23.0 & 11.0 \\
& In NEET population & 63.5 & 23.7 & 12.8 \\
& In YEI & 3.3 & 64.6 & 32.0 \\
Poland NEET population & 23.4 & 62.6 & 14.0 \\
& In YEI & 10.6 & 61.5 & 27.8 \\
& In NEET population & 23.6 & 70.0 & 6.4 \\
\hline
\end{tabular}

Source: Eurostat database and ESI Open Data Portal.

3 It should be noted that while the NEET figures referred to in this chapter cover the population aged 15-24, Spain, for instance, extended the spending of ESF money to programmes involving young people aged up to 29 . 
Table 10.8 Participants in YEI-funded programmes by employment status in percentages, 2015

\begin{tabular}{llccc}
\hline & Inactive & Unemployed & $\begin{array}{c}\text { Long-term } \\
\text { unemployed } \\
\text { as share of } \\
\text { unemployed } \\
\%\end{array}$ \\
\hline Spain & In YEI & & & 22 \\
& In NEET population & 32 & 71 & 83.4 \\
Greece & In YEI & & 68 & \\
Poland & In NEET population & 35 & 100 & 44.6 \\
& In YEI & 3.5 & 65 & \\
& In NEET population & 49 & 51 & \\
\hline
\end{tabular}

Source: ESI Open Data Portal.

Similarly, the data presented in Table 10.8 suggest that, so far, Spain has allocated resources according to the current labour market situation of young NEETs. The share of young unemployed and inactive NEETs corresponds fairly well to the share of young people taking part in YEI-funded measures. In contrast, Greece and Poland have concentrated their efforts mostly on young unemployed NEETs, even though their share of inactive NEETs - often the most discouraged and difficult to reach (Eurofound, 2012) - is very high. Because of the focus on young unemployed, a higher percentage of long-term young unemployed was involved in YEI measures in Poland and Greece.

To summarize, this section has shown that while countries have involved a higher share of young people in ESF-funded measures in the first two years of the current funding period than in the previous period, the pattern of distribution has remained similar. The comparison between the share of NEETs in the population by educational attainment and the YEI funds spent on young people by educational attainment gives a preliminary impression of how money has been spent across groups.

\section{CONCLUSION}

Overall the impression of the ESF's efforts and significance vis-à-vis young people at risk of long-term unemployment or precarity in the 2007-13 period is ambiguous. The exact and final outcomes of their participations in ESF measures are unclear. A preliminary expert evaluation carried out 
in 2014 based on the situation at the end of 2012 provides figures for young people's outcomes by country, whereas the final ex post evaluation does not. This divergence is not accounted for in the final synthesis report.

Apart from this shortcoming, the available statistics on participations by young people indicate diversity or heterogeneity in the recruitment of participants across countries. The comparison between the share of young participants and young people in need provide an indication of the efficacy of the efforts for young NEETs. The data also show that the effort to tackle young people's difficulties in the labour market in the first two years of the current funding period has intensified compared with the previous period.

In this chapter we have shown that member states have had great discretion in their 'usage' of the financial resources provided by the ESF. This discretion and heterogeneity add to the challenge of getting a clear and consistent picture of the accomplishments made based on ESF grants.

Moreover, even though this chapter has presented some comparative descriptions based on freely available data provided by the EU, our research efforts were frustrated by a lack of Europe-wide, properly harmonized statistics. This is arguably one of the reasons why the ESF has attracted little attention from welfare and social policy researchers. As long as such comparative data are missing, it will be difficult to advance research on the efficacy of the ESF and its significance for young people as well as for other vulnerable groups. At present poor data availability makes it impossible to apply more sophisticated quantitative research methods in analyses of the appropriateness of priorities and of outcomes.

Hence, in our view, critical factors for increasing the significance of the ESF in the future prevention of long-term unemployment and precarity amongst young Europeans include:

- Giving such prevention a much more sharply formulated priority, for instance by setting explicit size targets for the share of NEETs or dropouts to be recruited into ALMP, VET or other ESF-funded measures.

- Identification of the main kinds of means or types of measures to be used; more consistent and detailed categories of measures based on clear operationalization to enable comparison over time and between countries.

- Operationalization of such prevention in clear targets with key desired outcomes.

- A robust and coherent EU-wide system for collecting data on the achievement of targets. Data should be suitable for counterfactual analysis, which would enable better understanding of the real impact of measures on the target populations. 
- Data consisting of representative samples for all major sub-groups of participants. Longitudinal data extending to two years after the ESF measures, for example, would provide a more complete picture of long-term outcomes. Anonymized background data on participants particularly referring to their socioeconomic position would allow comparative assessments of success in reaching those most in need.

- Easier data access and management as well as easy coupling with existing and easily available data, such as via Eurostat, would facilitate high-quality research on the topic.

Addressing these elements may reduce the de facto scope for nationalspecific 'usages' of the ESF funds. In this regard a main priority should be closer monitoring and assessment of provisional achievements during programme periods, for instance of the kind of ongoing assessment and feedback we find in European-level policy coordination processes like the European Semester.

\section{REFERENCES}

Allen D (2005) Cohesion and structural funds. In: Wallace H, Wallace W and Pollack MA (eds) Policy-Making in the European Union. 5th ed. Oxford, UK: Oxford University Press, pp. 213-41.

Ashiagbor D (2005) The European Employment Strategy. Labour Market Regulation and New Governance. Oxford, UK: Oxford University Press.

Bonnet A (2015) The European Social Fund and the issue of reconciliation in Poland. Analele Universitatii Bucurestii Seria Stiinte Politice 27(1): 99-118.

Brine J (1992) The European Social Fund and the vocational training of unemployed women: Questions of gendering and re-gendering. Gender and Education 4(1/2): 149-62.

Brine J (1995) Equal opportunities and the European Social Fund: Discourse and practice. Gender and Education 7(1): 9-22.

Caliendo M and Schmidl R (2016) Youth unemployment and active labor market policies in Europe. IZA Journal of Labor Policy 5(1). DOI: 10.1186/ s40173-016-0057-x.

Council Decision 83/516/EEC of 17 October 1983 on the tasks of the European Social Fund. Official Journal of the European Communities L 289/38, 22.10.1983.

Council Regulation (EC) No 1260/1999 of 21 June 1999 laying down general provisions on the Structural Funds. Official Journal of the European Communities L 161/1, 26.6.1999.

Council Regulation (EC) No 1083/2006 of 11 July 2006 laying down general provisions on the European Regional Development Fund, the European Social Fund and the Cohesion Fund and repealing Regulation (EC) No 1260/1999. Official Journal of the European Union L 210/25, 11.7.2006.

Council Regulation (EEC) No 2052/88 of 24 June 1988 on the tasks of the 
Structural Funds and their effectiveness and on coordination of their activities between themselves and with the operations of the European Investment Bank and the other existing financial instruments. Official Journal of the European Communities L 185/9, 15.7.1988.

Council Regulation (EEC) No 2084/93 of 20 July 1993 amending Regulation (EEC) No 4255/88 laying down provisions for implementing Regulation (EEC) (No 2052/88 as regards the European Social Fund. Official Journal of the European Communities L 193/39, 31.7.1993.

Dănescu T and Dogar C (2012) COSO Principles and European Social Fund funded projects in Romania. Procedia - Social and Behavioral Sciences 62: 901-5. DOI: 10.1016/j.sbspro.2012.09.152.

De la Porte C (2017) EU governance of welfare states and labour markets. In: Kennett P and Lendvai-Bainton N (eds) Handbook of European Social Policy. Cheltenham, UK and Northampton, MA, USA: Edward Elgar Publishing, pp. 141-54.

Directorate-General for Regional Policy (2008) EU Cohesion Policy 1988-2008: Investing in Europe's Future. InfoRegio Panorama 26. Luxembourg: Publications Office of the European Union.

ESF Expert Evaluation Network (2014) Final Synthesis Report: Main ESF Achievements, 2007-2013. Brussels: Directorate-General for Employment, Social Affairs and Inclusion.

EUR-LEX (nd) Access to European Union Law. https://eur-lex.europa.eu (accessed 31 May 2018).

Eurofound (2012) NEETs - Young People not in Employment, Education or Training: Characteristics, Costs and Policy Responses in Europe. Luxembourg: Publications Office of the European Union.

European Commission (1999) Reform of the Structural Funds 2000-2006. Comparative Analysis. Brussels: European Commission. http://ec.europa.eu/regional_policy/ sources/docoffic/official/regulation/pdf/irfo_en.pdf (accessed 22 February 2018).

European Commission (2016a) ESF Ex post Evaluation Synthesis 2007-2013. Country Report - Bulgaria. Brussels: Directorate-General for Employment, Social Affairs and Inclusion.

European Commission (2016b) ESF Ex post Evaluation Synthesis 2007-2013. Country Report-Czech Republic. Brussels: Directorate-General for Employment, Social Affairs and Inclusion.

European Commission (2016c) ESF Ex post Evaluation Synthesis 2007-2013. Country Report - Germany. Brussels: Directorate-General for Employment, Social Affairs and Inclusion.

European Commission (2016d) ESF Ex post Evaluation Synthesis 2007-2013. Country Report-Greece. Brussels: Directorate-General for Employment, Social Affairs and Inclusion.

European Commission (2016e) ESF Ex post Evaluation Synthesis 2007-2013. Country Report-Poland. Brussels: Directorate-General for Employment, Social Affairs and Inclusion.

European Commission (2016f) ESF Ex post Evaluation Synthesis 2007-2013. Country Report - Spain. Brussels: Directorate-General for Employment, Social Affairs and Inclusion.

European Commission (2016g) ESF Ex post Evaluation Synthesis 2007-2013. Country Report-United Kingdom. Brussels: Directorate-General for Employment, Social Affairs and Inclusion. 
European Commission (2016h) ESF Ex-post Evaluation. Synthesis 2007-2013. EU Synthesis Report-Final Version. Brussels: Directorate-General for Employment, Social Affairs and Inclusion.

European Commission (2016i) Commission Staff Working Document: Ex-post evaluation of the 2007-2013 ESF programmes. Brussels: SWD(2016) 452 final.

Goetschy J (1999) The European employment strategy: Genesis and development. European Journal of Industrial Relations 5(2): 117-37.

Lindley RM (1996) The European Social Fund: A strategy for generic evaluation. In: Schmid G, O'Reilly J and Schömann K (eds) International Handbook of Labour Market Policy and Evaluation. Cheltenham, UK and Northampton, MA, USA: Edward Elgar Publishing, pp. 843-67.

Majone G (1993) The European Community between social policy and social regulation. Journal of Common Market Studies 31(2): 153-170.

Manzella GP and Mendez C (2009) The turning points of EU cohesion policy. Report Working Paper for Barca Independent Report. http://aer-www.ameos. net/fileadmin/user_upload/MainIssues/CohesionRegionalPolicy/2010/Barca-Re port.pdf (accessed 12 June 2018).

Regulation (EC) No 1262/1999 of the European Parliament and of the Council of 21 June 1999 on the European Social Fund. Official Journal of the European Communities L 161/48, 26.6.1999.

Regulation (EC) No 1081/2006 of the European Parliament and of the Council of 5 July 2006 on the European Social Fund and Repealing Regulation (EC) No 1784/1999. Official Journal of the European Union L 210/12, 31.7.2006.

Regulation (EU) No 1303/2013 of the European Parliament and of the Council of 17 December 2013 laying down common provisions on the European Regional Development Fund, the European Social Fund, the Cohesion Fund, the European Agricultural Fund for Rural Development and the European Maritime and Fisheries Fund and laying down general provisions on the European Regional Development Fund, the European Social Fund, the Cohesion Fund, the European Agricultural Fund for Rural Development and the European Maritime and Fisheries Fund and repealing Council Regulation (EC) No 1083/2006. Official Journal of the European Union L 347/320, 20.12.2013.

Regulation (EU) No 1304/2013 of the European Parliament and of the Council of 17 December 2013 on the European Social Fund and repealing Council Regulation (EC) No 1081/2006. Official Journal of the European Union L 347/470, 20.12.2013.

Sanchez Salgado R (2013) From 'talking the talk' to 'walking the walk': Implementing the EU guidelines on employment through the European Social Fund. European Integration Online Papers 17(Article 2): 1-26.

Tomé E (2012) European Social Fund in Portugal: A complex question for human resource development. European Journal of Training and Development 36(2/3): 179-94. DOI: 10.1108/03090591211204706.

Tosun J, Speckesser S, Jensen C and O'Reilly J (2017) The absorption of Structural and Investment Funds and youth unemployment. In: Bachtler J, Berkowitz P, Hardy S and Murawska T (eds) EU Cohesion Policy: Reassessing performance and direction. London, UK and New York, US: Routledge, pp. 151-68.

Van Gerven M, Vanhercke B and Gürocak S (2014) Policy learning, aid conditionality or domestic politics? The Europeanization of Dutch and Spanish activation policies through the European Social Fund. Journal of European Public Policy 21(4): 509-27. DOI: 10.1080/13501763.2013.862175. 
Verschraegen G, Vanhercke B and Verpoorten R (2011) The European Social Fund and domestic activation policies: Europeanization mechanisms. Journal of European Social Policy 21(1): 55-72. DOI: 10.1177/0958928710385733.

Zimmermann K (2016) Local responses to the European Social Fund: A cross-city comparison of usage and change. JCMS: Journal of Common Market Studies 54(6): 1465-84. DOI: $10.1111 /$ jcms.12395. 